\title{
O ensino a distância e os avanços para a pesquisa em enfermagem
}

\author{
Elioenai Dornelles Alves ${ }^{1}$
}

A educação a distância (EaD) sempre foi questionada no meio acadêmico por motivos diversificados. Dentre estes merecem destaque: as críticas sobre a produção em massa de diplomas em instituições privadas; o uso de metodologias questionáveis; a valorização excessiva da tecnologia em detrimento do conteúdo; a realização de atividades presenciais sem justificativas didático-pedagógicas adequadas; e a concepção de que o ensino a distância não oportuniza a humanização da aprendizagem, exclui os que não têm condições econômicas, e de que nem todos estão preparados para o exercício de uma aprendizagem autônoma.

A partir de nossa experiência na utilização dessa tecnologia há mais de onze anos na área de Enfermagem e Saúde, podemos dizer que os problemas relacionados à formação de pessoas em EaD são decorrentes de alguns aspectos, tais como a falta de formação político-andragógica do educador para docência; necessidade de ampliação das discussões sobre a real importância do uso da EaD e do ensino semipresencial no espaço das Instituições de Ensino Superior (IES); e a falta de produção de conhecimentos específicos sobre os fatores limitadores e das possibilidades para avanços da EaD na área de educação e saúde.

No que diz respeito à formação do educador, acreditamos que o problema esteja diretamente relacionado à falta de uma formação política desse educador, pois nossos currículos enfatizam uma carga de conteúdos predominantemente técnica sem destaque para a formação humana e política. O ensino presencial dentro de um modelo tradicional e tecnicista como opção para o ensino é outra questão que merece um grande aprofundamento na área de saúde e enfermagem, pois na educação já vem sendo feito há mais de três décadas.

Na pedagogia a ênfase é para o ensino de crianças e na andragogia o aluno é adulto. Não temos preparo suficiente para educar nem crianças, nem adultos, o que resulta em uma réplica do modelo tradicional de educação, destacado pelos teóricos como uma educação bancária, reprodutivista, injusta e excludente. Mas como entender tudo isso se nossa formação é assim? Não é difícil, estamos formados, mas não informados para o exercício pleno da cidadania e da democratização do saber que oportuniza ao aprendiz as mais diferentes formas de acesso e de aprendizagem.

Nossos argumentos sobre a importância dessa estratégia de ensino-aprendizagem advêm da nossa produção científica e das experiências bem-sucedidas vivenciadas na última década em projetos de EaD relacionados à pesquisa(1), ao ensino(2) e à extensão universitária(3). Nosso vínculo e compromisso com o ato educativo estão associados à fala de Paulo Freire que diz: que se não fosse por amor, não seríamos educadores.

Na década de 1990, a busca por melhorias no ensino de graduação em enfermagem, com os projetos Integração Docente Assistencial (IDA) e Uma Nova Iniciativa na Educação dos Profissionais do Setor de Saúde (PROUNI), contribuiu para um salto qualitativo nas inovações curriculares da enfermagem. É dessa década que destacamos o Programa de Desenvolvimento da Enfermagem na América Latina (PRODEN) que oportunizou a capacitação de docentes de enfermagem, utilizando o ensino a distância. Também ressaltamos a forte influência dos Seminários Nacionais de Diretrizes para a Educação em Enfermagem no Brasil (SENADEn) ${ }^{(1)}$, no ano de 1994, quando houve um diagnóstico da situação da formação e da necessidade de definição das diretrizes da educação para enfermagem brasileira.

No ensino de graduação na área de saúde, em instituições públicas, as reflexões sobre o uso da EaD e das mídias educacionais são ainda incipientes, embora inúmeras instituições de ensino já as utilizem em treinamentos, em disciplinas semipresenciais e como apoio ao ensino presencial. Portanto, o fato de tais experiências não passarem por avaliações capazes de mensurar sua efetividade impossibilita conclusões sobre o impacto da opção metodológica em questão. 
Neste contexto, há a necessidade de acompanharmos e produzirmos conhecimentos que estejam associados aos avanços da EaD e das novas leis, em pesquisas relacionadas ao compromisso com: a educação a distância (público e privado); a formação dos profissionais da saúde como educadores, com capacitação e aperfeiçoamento permanente do docente; o planejamento da prática educativa, repensando os modelos de ensino e de avaliação; e a política de capacitação e qualificação no trabalho para melhoria do desempenho docente.

O Art. 43 da Lei de Diretrizes e Bases (LDB/96) em seus incisos estimula o desenvolvimento científico e do pensamento reflexivo e incentiva a pesquisa para o desenvolvimento da ciência e da tecnologia(2). Nestes aspectos podemos destacar que, apesar do conhecimento produzido comprometer-se com a humanização do cuidado, pesquisas que versam sobre prática educativa em enfermagem não têm sido prestigiadas. Outro aspecto muito importante desse artigo na lei é a legitimação da autonomia e a flexibilidade das universidades, resguardando as instâncias deliberativas institucionais de seus projetos político-pedagógicos, já assegurados na Constituição Federal Brasileira de 1988 em seus artigos 207 - enfatizando que as universidades gozam de autonomia didático-pedagógica e administrativa - e 208 - diz que cabe ao Estado garantir o acesso.

No que se refere à educação a distância, a LDB, no art. 80, regula a matéria destacando que o Poder Público incentivará o desenvolvimento e a veiculação de programas de EaD, em todos os níveis e modalidades de ensino, e de educação continuada. Posteriormente, com base na LDB, o MEC regulamentou por meio da Portaria № 4.059 de 10 de Dezembro de 2004 a oferta de disciplinas semipresenciais nas Instituições de Ensino Superior, limitando a oferta da modalidade de ensino a $20 \%$ da carga horária total do curso e definindo que as avaliações deverão ser presenciais ${ }^{(4)}$. Em 2005, o Decreto No 5.622, de 10 de Dezembro de 2005, regulamentou o art. 80 da LDB, estabelecendo, em seu artigo 9o, critérios para o credenciamento de instituições ao ensino superior

Assim, a legislação brasileira regulamenta e viabiliza a utilização das tecnologias da informação e comunicação aplicadas à educação e à pesquisa, possibilitando o surgimento de políticas públicas dirigidas à democratização da educação em saúde, facilitando o processo de ensino-aprendizagem de graduação e de pós-graduação e rompendo as barreiras impostas pelo tempo e pela localização geográfica.

\section{REFERÊNCIAS}

1. Santana FR, Gaspar CC, Costa RA, Paica VG, Rodrigues MCS, Alves ED. Educação à distância nas instituições federais de ensino superior: a situação da enfermagem brasileira. Rev. Eletr. Enf. [Internet]. 2005 [cited 2012 sep 30];7(1):41-53. Available from: http://www.fen.ufg.br/revista/revista7 1/original 04.htm.

2. Alves ED, Kusano MSE, Serpa MGN, Kusano LME, Quaresma M. Añejos y avances en la utilizacion de la internet para la enseãnanza superior de enfermería en el Brasil. Revista Panamericana de Enfermeria. 2004;2(1):14-23.

3. Peixoto HM. Avaliação de disciplinas semipresenciais de graduação e pós-graduação na área de promoção da saúde na Universidade de Brasília [dissertathion]. Brasília: Departamento de Enfermagem/UnB; 2012.

4. Teatini, JC. MEC promete triplicar matrículas em EAD e alcançar 600 mil alunos até 2014 [Internet]. São Paulo: UOL Educação [update 2012 apr 24, cited 2012 sep 30]. Available from: http://educacao.uol.com.br/noticias/2012/04/24/mec-promete-triplicar-matriculas-em-ead-ate-2014-e-alcancar-600mil-alunos.htm.

${ }_{1}^{1}$ Enfermeiro, Doutor em Enfermagem. Professor Titular, Livre Docente, Coordenador do Laboratório de Educação, EAD e Promoção da Saúde, Programa de Pós-Graduação em Enfermagem, Faculdade de Ciências da Saúde, Universidade de Brasília. E-mail: elioenai@unb.br. 